\title{
Motivation of Japanese Descending Diaspora Entrepreneurs
}

\begin{abstract}
Aki Harima*
This paper explores entrepreneurial motivation of Japanese diaspora entrepreneurs conducting their business in emerging countries. While diaspora entrepreneurs play an increasingly significant role in the modern transnationalizing economy (Newland \& Tanaka, 2010), previous scholars have predominantly focused on those who originate from developing countries and migrate to more developed ones. There are, however, also entrepreneurs who originate from developed countries and establish their business in emerging countries. These people are almost invisible in the previous research even though their entrepreneurial activities are assumed to have positive impacts on the local economy. They transfer knowledge, resources and information from developed countries to emerging countries. In the first place, it sounds rather counter-intuitive that they move from richer and more secure contexts to apparently less attractive conditions. We know still very little about their entrepreneurial motivations. This paper takes a first step to investigate their highly complex motivations by conducting multiple case studies with Japanese entrepreneurs in several emerging countries. The central research question to be answered is: what drives Japanese diasporans to become entrepreneurs in emerging countries? A grounded theory (Charmaz, 2014) approach will be chosen and the empirical data will be analyzed descriptively and coded. At the end of this paper, six main motivational factors are identified through an empirical study.
\end{abstract}

Keywords: entrepreneurial motivation, diaspora entrepreneurship, descending diaspora entrepreneurs.

Submitted: 21.07.2015 | Accepted: 28.09.2015

\section{Motywacja przedsiębiorców diaspory japońskiej będących potomkami emigrantów}

$W$ artykule zaprezentowano motywację przedsiębiorcza członków diaspory japońskiej prowadzacych dziatalność gospodarcza $w$ krajach wschodzacych. Pomimo że odgrywaja oni coraz ważniejsza rolę we wspótczesnej transnarodowej gospodarce (Newland i Tanaka, 2010), badacze dotychczas głównie koncentrowali się na przedsiębiorcach pochodzacych z krajów rozwijajacych się i migrujących do krajów bardziej rozwiniętych. Niemniej jednak także przedsiębiorcy pochodzacy z krajów rozwiniętych zaktadaja przedsiębiorstwa w krajach wschodzacych. Osoby te byty z reguty pomijane $w$ dotychczasowych badaniach, chociaż zaktada się, że ich dziatania przedsiębiorcze maja pozytywny wptyw na gospodarke lokalna. Wnosza one bowiem do krajów wschodzacych wiedzę, zasoby i informacje z krajów rozwiniętych. Przede wszystkim stosunkowo sprzeczne z intuicją wydawać się może to, że przenosza się ze środowisk bardziej bezpiecznych $w$ miejsca o warunkach najwyraźniej mniej atrakcyjnych. Wiedza o czynnikach skłaniajacych je do podejmowania działań przedsiębiorczych jest nadal niewielka. W artykule po raz pierwszy przedstawiono bardzo złożone czynniki motywacyjne na podstawie wielu studiów przypadku przeprowadzonych wśród przedsiębiorców japońskich w krajach wschodzacych. Główne pytanie

\footnotetext{
Aki Harima - University of Bremen.

Adres do korespondencji: Wilhelm-Herbst-Straße 5, 28359 Bremen, Germany, Chair in Small Business \& Entrepreneurship (LEMEX), University of Bremen, harima@uni-bremen.de.
} 
badawcze brzmi: co sktania członków diaspory japońskiej do podjęcia dziatań przedsiębiorczych w krajach wschodzacych? Wybrana metoda jest teoria ugruntowana (Charmaz, 2014), zgodnie z która dokonano opisowej analizy i kodowania danych empirycznych. W koncowej części artykutu, opierając się na badaniu empirycznym, określono sześć głównych czynników motywacyjnych.

Słowa kluczowe: motywacja przedsiębiorcza, przedsiębiorczość diaspory, przedsiębiorcy diaspory-potomkowie emigrantów.

Nadesłany: 21.07.2015 | Zaakceptowany do druku: 28.09.2015

JEL: F22, L26

\section{Introduction}

Globalization enables different forms of human mobility around the world. While previous researchers have focused on the migrants who migrate from developing or emerging countries to developed countries in migration waves (cf. Brinkerhoff, 2004; Cohen, 2008; Newland \& Tanaka, 2010; Ojo, 2012; Ojo et al., 2013; Tchouassai \& Sikod, 2010), we recently observe different types of human mobility beyond national borders (Elo, 2013; Horiuchi, 2010; Harima, 2014). For instance, there are German entrepreneurs in South Africa and American entrepreneurs in Latin America. They migrate to economically less developed contexts and become entrepreneurs. These entrepreneurs are named as "Descending Diaspora Entrepreneurs" (Harima, 2014). These people are assumed to have positive impacts on both their country of origin and country of residence, as they not only create jobs, but also transfer knowledge, technology, institutions as well as financial capitals from developed countries to emerging and developing countries.

In the previous research on diaspora entrepreneurship, their presence is almost invisible. Therefore, we do not know why these people migrate to less economically developed contexts and become entrepreneurs. Traditionally, one of the primary reasons for migration was to seek a better life (cf. Cohen, 1996). Migrants are believed to move to the countries which have better economic, political and societal conditions. However, the home countries of descending diaspora entrepreneurs are developed countries and therefore offer preferable conditions. For this reason, this paper addresses the research questions: (i) Which multi-level environmental fac- tors influence motivation formulation of Descending Diaspora Entrepreneurs?; (ii) What are the key motivational factors of such entrepreneurs?

Multiple case studies with 8 Japanese entrepreneurs in emerging countries have been conducted. Based on an inductive analysis, this paper suggests a possible mechanism of influencing factors and presents six main motivational factors of Japanese entrepreneurs. The main contribution of this paper is that it illuminates diaspora entrepreneurs from developed countries and explores their complex mixed motivations by considering their country specific contexts as well as the literature on diaspora entrepreneurship and entrepreneurship.

\section{Conceptual Background}

\subsection{Entrepreneurial Motivation}

Motivation has been regarded as an essential factor in entrepreneurship by previous researchers (Van Gelderen et al., 2008; Yalcin \& Kapu, 2008). Motivation has significant impacts on entrepreneurship. Van Eerde and Thierry (1996) argue that an entrepreneur's motivation may influence his or her intention, intended effort, task performance, and time spent on their task. The impact of entrepreneurial motivation on venture success has also been investigated by some researchers (Kuratko et al., 1997; Robichaud et al., 2001).

In the early days, reasons for becoming an entrepreneur were considered to be economic (Schumpeter, 1934). Yet, previous studies find out that it is typically not a primary motivation to start an own business to make more money (Hamilton, 1988; Scheinberg \& MacMillan, 1988). There- 
fore, previous researchers have made considerable efforts to explore non-economic psychological motivations of entrepreneurs.

Among others, achievement motivation (a need for achievement) is probably most frequently argued as an essential entrepreneurial motivation (cf. McClelland, 1961; Homaday \& Bunker, 1970; Atkinson, 1957; Davidsson, 1989; 1991). Achievement motivation refers to one's expectation of doing something better or faster than anybody else or better than the person's own earlier accomplishments (Hansemark, 2003). It could be learned and may develop according to how the individual's existing frame of reference is put against the individual's own desire to achieve (McClelland, 1990). McClelland's argumentation that those with high motivation of this kind will be more likely to pursue entrepreneurial career than other populations has been tested by researchers in different contexts. While McClelland (1961) concluded, based on empirical research, that achievement motivation is not a major determinant of entrepreneurship, a number of studies have proven a positive relationship between achievement motivation and a decision to become entrepreneurs (Johnson, 1990; Babb \& Babb, 1992; Shaver \& Scott, 1991; Collins et al., 2004). Several researchers have further conducted research on sub-dimensions of this concept including mastery needs, work orientation and interpersonal competitiveness by arguing that different dimensions of achievement motivation co-exist within individuals (Carsrud \& Brännback, 2011).

Besides achievement motivation, there are several types of entrepreneurial motivation. The need for independence has also been frequently stated as a reason for founding an own firm (Bamberger, 1986; Scheinberg \& MacMillan, 1988; Hamilton, 1988; Robichaud et al., 2001). Scheinberg and MacMillan (1988) identified six categories of entrepreneurial motivation based on their survey in 11 different countries: (i) the need for approval; (ii) the instrumentally perceived wealth, (iii) degree of communitarianism, (iv) the need for personal development, (v) the need for independence, and (vi) the need for escape. In a similar vein, Westhead (1994) identified seven motivational factors based on a survey with British entrepreneurs: (i) the need for approval, (ii) the need for personal development, (iii) welfare considerations, (iv) the perceived instrumentality of welfare, (v) tax reduction, and (vi) the example of role models. While such categories offer a certain understanding, they do not provide a holistic view of this topic.

In order to create a big picture, some researchers have attempted to develop a more systematic view of entrepreneurial motivation. A well-known example is a classification into push and pull motivational factors for entrepreneurship. According to Amit and Muller (1995), "push" entrepreneurs refer to those who are pushed out of the current employment, while "pull" entrepreneurs are pulled out of the current position. Amit and Muller find out that pull entrepreneurs are more successful than push entrepreneurs. Similar concepts to "pull" and "push" factors are opportunity and necessity entrepreneurship (Smallbone \& Welter, 2004). Another example is a classification into intrinsic and extrinsic motivation. Intrinsic motivation refers to psychological rewards, for instance, being one's own boss or having ultimate responsibility for ventures, while extrinsic motivation is financial or other tangible rewards from business (Choo \& Wong, 2006). In some previous studies, entrepreneurs who are mainly motivated by intrinsic motivation are more successful (Bird, 1989; Volery et al., 1977). Differences between genders have been also considered by several studies (cf. Okafor \& Amalu, 2010; Singh, 1993). There are also some attempts to look at how individuals perceive the overall combination of different extrinsic and intrinsic factors and make a decision to become entrepreneurs, for instance, the concept of reward structure (Baumol, 1990; Campbell, 1992; Praag \& Cramer, 2001; Renko et al., 2012). An expected reward depends on assessments of individual ability, attitudes towards risk, perception of entrepreneurial feasibility.

Individuals who conduct an own business are highly diversified regarding nationality, culture, demographic characteristics and qualifications. Entrepreneurial motivation can be influenced by several factors. For instance, personal motivation to become an entrepreneur is related to individual income (Smallbone \& Walter, 2001) or educational background (Arenius \& Minniti, 2005). The nature of business can also influence entrepreneurial motivation. For 
instance, advocacy motivation characterizes social entrepreneurs (London, 2010). Despite a number of studies conducted on this topic, a transnational dimension has not fully been considered in the previous research.

\subsection{Diaspora Entrepreneurship}

The diaspora refers to the migrants and their descendants who maintain a strong relationship to their country of origin (Safran, 1991). Diaspora and their business activities have attracted increasing research interest due to the growing migration phenomenon as well as its changing nature (Aldrich et al., 1990; Sanders et al., 1996; Riddle et al., 2010; Vemuri; 2014). According to the International Migration Outlook from OECD (2013), there were 232 million people living outside their country of birth around the world in 2013, which represents 3.2 percent of the world's population. If migration continues to grow at the same pace as over the past twenty years, there will be 405 million migrants by 2050 in the world (International Organization for Migration, 2014). As the migration trend is increasing, the number of diaspora is assumed to be growing. The recent technological development in communication and transportation sector enables migrants and their descendants to maintain a strong emotional connection to their country of origin (COO) and therefore identify themselves through $\mathrm{COO}$ even many years after migration (Yeung, 2002; Riddle, 2008).

The diaspora has been regarded as a unique contributor to the world. Remittance sent by diasporans to their COOs is probably one of the most well-recognized contribution forms. According to the Bilateral Remittance Matrix 2012 (World Bank, 2012), the total amount of the worldwide inward and outward remittance in 2012 was approximately USD 529 billion. The impact of remittance is especially significant on developing countries (Minto-Coy, 2010; Rubyutsa, 2012; Orozco, 2009). The form of their homeland investment is diversified. Diaspora Direct Investment (DDI) plays also a significant role for different reasons. Huang \& Khanna (2003) argue that the rapid economic development which China and India experienced in the recent years would have not been possible without DDI. DDI is essential not only for the national economy of such economic giants, but also smaller countries in difficult political conditions such as conflicts or lack of resources, since they cannot easily attract usual foreign direct investment. Diasporans are believed to invest in their $\mathrm{COO}$ not only for strategic reasons, but also for philanthropic reasons (Ketkar \& Ratha, 2010; Nielsen \& Riddle, 2009). Besides financial contributions, diasporans make various forms of contributions both for their $\mathrm{COO}$ and country of residence (COO) through peace development (Brinkerhoff, 2006; 2011; Kent, 2005; Mohamoud \& Osman, 2008), technology/knowledge transfer (Saxenian, 2002; 2005; Kapur, 2001, Meyer, 2007), innovation (Lin, 2010), and institution transfer (Riddle \& Brinkerhoff, 2011).

Diaspora entrepreneurship describes entrepreneurial activities conducted by diasporans who leverage their unique diaspora resources. Their international entrepreneurial activities have become increasingly important (Nkongolo-Bakenda \& Chrysostome, 2013). The diaspora population possess unique resources due to their mixed embeddedness in $\mathrm{COO}$ and COR (Kloostermann et al., 1999). For instance, diaspora entrepreneurs are assumed to have an access to Diaspora Network (Kuznetsov, 2006; Light et al., 1989; Lebang, 2011; Dutia, 2011; Elo, 2014). Such a mixed embeddedness also allows diasporans to recognize idiosyncratic opportunities, as opportunities are closely linked to their embeddedness in economic, political-institutional, and social environments (Rath, 2000).

Despite their substantial contribution in various forms, we still do not discern a big picture of their entrepreneurial activities. One of the main explanations is a high degree of heterogeneity and uniqueness of their entrepreneurial activities, which impedes generalizations of findings of previous studies. Although there are various types of flows in migration, previous studies have predominantly focused on entrepreneurial activities of the diasporans originating from developing or emerging countries who migrate to more economically developed contexts (Harima, 2014; Elo, 2013). Harima (2014) names them "Ascending Diaspora Entrepreneurs". However, there are also diasporans from developed countries who migrate to other countries including developing or emerging countries ("Descending Diaspora Entrepreneurs"; Harima, 2014). 
These diasporans are assumed to make a contribution to their $\mathrm{COO}$ and COR through their entrepreneurial activities in different ways. Only a few studies, however, have been conducted on this type of diaspora entrepreneurs.

This paper focuses on descending diaspora entrepreneurs. Such people seem to have different kinds of motivation from ascending diaspora entrepreneurs. They make a decision to leave their home country whose economic condition as well as social standards are high in order to migrate to a country with lower standards. Their entrepreneurial motivation has not been explored in the previous literature.

\section{Motivation of Diaspora Entrepreneurs}

Although previous studies have predominantly focused on ascending diaspora entrepreneurship, some findings on such entrepreneurs offer a few hints to us to understand entrepreneurial motivation of descending diaspora entrepreneurs to a certain extent. Among others, Nielsen and Riddle (2007) offer an essential classification concerning diaspora motivation into three following categories: (i) financial motivation; (ii) social motivation; (iii) emotional motivation.

First, diasporans may be driven by a potential of financial returns of investment. Nielsen and Riddle (2007) argue that diasporans are more likely to be driven by financial motivation when they feel homeland bias and investment confidence which reduce their risk perception toward investment. According to Nielsen and Riddle (2007), homeland bias refers to the exacerbated perception of the probability of success of their investment when they invest in their COO due to the familiarity with the context. The investment confidence can be enhanced through vocational experiences of diasporans. Gillespie et al. (1999) point out a diaspora-specific advantage in relation to the financial motivation and name it "ethnic advantage". Immigrants often believe that people with the same ethnic background can better ascertain and meet the needs of their immigrant community. Therefore, immigrant entrepreneurs have a propensity to offer services and products specific to the ethnic community (Bonacich \& Modell, 1980).
While these arguments for the financial motivation seem to be rather opportunitydriven, some researchers also discuss that diasporans are driven by negative factors in COR due to a lack of vocational alternatives or inappropriate salaries compared to the local population (Constant \& Shachmurove, 2003; Constant et al., 2002; Lofstrom, 1999). Sometimes, it is called "the economic dead-end theory" and regarded as one of the primary reasons for entrepreneurial activities of migrants and diasporans (Kalltany \& Visser, 2010; Fatoki \& Patswawairi, 2012; Thomsen, 2006; Barrett et al., 2001; Basu \& Altinay, 2002; Malcalf et al., 1996). In such cases, diasporans are motivated to increase their income through choosing an entrepreneurial career. It is, however, questionable to which extent we can apply this statement to descending diaspora entrepreneurs.

The second category of diaspora motivation is related to a social aspect. Social motivation is related to diaspora individuals' feeling of belongings to the community or ethnic group. According to NkongoloBakenda and Chrysotome (2013), diasporans engage in homeland investment activities, seeking for social recognition from their diaspora and homeland communities. Nilsen and Riddle (2007) further point out the role of "homeland duty", which describes the feeling of diasporans of being obliged to invest in their COO. Such a feeling is constructed as a result of socialization with their family, friends and other countrymen in their daily life.

The third category is emotional investment motives. Gillespie et al. (1999) identify emotional feelings of altruism as one of the main motivations of diasporans to invest in their homeland. Altruistic motivation has attracted considerable research interest in the previous diaspora research (Tchoussai \& Sikod, 2010; Poirine, 2006; Brinkerhoff, 2008). Diaspora entrepreneurs may be driven by the altruistic mission to improve political or economic conditions as well as a quality of life of the people in COO.

Although these previous findings certainly offer some hints regarding entrepreneurial motivation of descending diasporans, they do not offer convincing argumentation to allow this paper to develop concrete assumptions. One reason is overconcentration of previous stud- 
ies on ascending diaspora entrepreneurs. As descending diaspora entrepreneurs do have a different starting point and overall environments, it is unknown to which extent earlier findings are applicable to this context. Another reason is a lack of consideration of the on-going discussion on the topic of entrepreneurial motivation. To many of former studies on diaspora motivation, the findings from the entrepreneurship research have not even applied. Some researchers have attempted to use a part of the findings such as a need for achievement as one of many socio-cultural measures in their quantitative studies (Fatoki \& Patswawairi, 2012; Masurel et al., 2001; Constant \& Shachmurove, 2003). As diasporans are in a complex transnational constellation and have idiosyncratic emotional feelings about their ethnicity as well as identity, the applicability of such findings should be carefully discussed.

\section{Research Design}

In order to explore entrepreneurial motivation of descending diaspora entrepreneurs, multiple case studies on 8 Japanese entrepreneurs in emerging countries were conducted with a grounded theory approach (Eisenhardt, 1989; Charmaz, 2014) between summer 2014 and spring 2015 by the author. According to Charmaz (2014), grounded theory methods "consist of systematic, yet flexible guidelines for collecting and analyzing qualitative data to construct theories from the data themselves". It enables an iterative research strategy for this study to go back and forth between inductive data from descending diaspora entrepreneurs and emerging analysis through reflecting findings of previous studies discussed above.

As for data selection, cases are carefully chosen, as "selection of an appropriate population controls extraneous variation and helps to define the limits for generalizing the findings" (Eisenhardt, 1989). All of the entrepreneurs fulfill the following requirements. First, this study investigates only entrepreneurs who originate from Japan in order to avoid variations caused by $\mathrm{COO}$ contexts and enable incorporation of Japanese societal factors into the analysis. Second, they left Japan in order to start their business in emerging countries. This selection allows this paper to avoid the confusion between motivation for emigration and motivation for entrepreneurship. Third, they can be regarded as diasporans who have a hybrid identity (Brinkerhoff, 2012; Kloostermann et al., 1999) in order to avoid confusion with expatriates. Fourth, only the first generation of migrants are selected so that generational variations do not affect the results. 6 emerging countries are selected as COR (Philippines, Guatemala, Chile, Argentina, India, and China) to observe COR-variations. These countries differ in various aspects including the availability of existing diaspora network, history of Japanese migrants, national institutions, culture, economic conditions as well as political situations.

Both primary and secondary data are collected. In the data collection process, the author fully considered the following points to evaluate the quality of data: (i) to collect enough background data about entrepreneurs, processes, and setting to have ready recall and to understand and portray the full range of contexts of the study; (ii) to gain multiple views of the entrepreneurs' views and actions; (iii) to gather data that enable this study to develop analytic categories (Charmaz 2014:33). As for the primary data, the author visited company locations in the Philippines, Chile and Argentina. This visit allowed the author to conduct an on-sight observation and casual interviews with various related people like employees, family members and customers. During the stay, pictures and notes were taken. On the locations which the author could not physically visit, Skype interviews with founders and related people like employees were conducted which took on average 80-120 minutes. As for the secondary data, corporate websites were analyzed in detail for the purpose of data triangulation (Denzin, 1970) in all of the 8 cases. Additionally, daily and weekly updates in social media such as Facebook and Twitter of founders were screened in Cases 1, 2, $3,4,6,8$. The overview of primary data is given in Table 1 .

Interviews were conducted in Japanese and English all by the author. Conducted interviews were transcribed and manually coded after descriptive analysis. After initial coding, value coding (Saldaña, 2008) was made with theoretical sampling, which means "seeking and collecting pertinent data to elaborate and refine categories in 
Table 1. Overview of 8 empirical cases

\begin{tabular}{|l|l|l|c|c|l|}
\hline & \multicolumn{1}{|c|}{ COR } & \multicolumn{1}{|c|}{ Sector } & Start year & Age & \multicolumn{1}{|c|}{ Primary Data } \\
\hline 1 & Philippines & Online English course & $2010-2015$ & $30-35$ & Skype (founder + employee) \\
\hline 2 & Philippines & English school & $2000-2010$ & $35-40$ & $\begin{array}{l}\text { Field research (founder, } \\
\text { employees \& customers) }\end{array}$ \\
\hline 3 & Guatemala & Online Spanish school & $2010-2015$ & $25-25$ & Skype (founder) \\
\hline 4 & Chile & Café \& Hostel & $2010-2015$ & $35-40$ & Field research (founder, partner) \\
\hline 5 & Argentina & Trading, logistics & $1980-1990$ & $65-70$ & $\begin{array}{l}\text { Field research (founder, } \\
\text { employees) }\end{array}$ \\
\hline 6 & India & English school & $2010-2015$ & $30-35$ & Skype and face2face (founder) \\
\hline 7 & Philippines & Manufacture, HR & $1980-1990$ & $65-70$ & $\begin{array}{l}\text { Skype and field research } \\
\text { (founder, employees) }\end{array}$ \\
\hline 8 & China & Consulting & $2010-2015$ & $25-30$ & Skype (founder) \\
\hline
\end{tabular}

your emerging theory" (Charmaz 2014; 192). Based on the analysis, a possible mechanism of entrepreneurial motivation is discussed. In the end, this paper presents 5 generic types of motivational combinations based on 6 main factors which are significant to the observed entrepreneurs.

\section{Motivation of Japanese Descending Diaspora Entrepreneurs}

The conducted case studies present various factors which influence entrepreneurial motivation of descending diaspora entrepreneurs on macro, meso and micro levels. In this section, it is shown how different factors on different levels of the analysis may be interrelated to each other to formulate their entrepreneurial intention.

On the macro level, mainly three factors which indirectly influence their entrepreneurial motivation are identified: (i) globalization, (ii) technology development, and (iii) economic gap. First, globalization here refers to the worldwide movement toward economic, financial, trade, and communications integration as well as the global human mobility. Second, the cases show also that technological development especially in communication and transportation sectors was relevant to their motivation. Third, the overall economic situation in Japan and in CORs plays also an important role in their environment.

These three macro-level factors change various environmental factors of individuals in Japan on the meso level. First, the worldwide trend of globalization enables the Japanese to move to foreign countries more easily than before. In a similar vein, Japanese people have the natural privilege of meeting people from other cultural contexts in their course of life.

Due to the first environmental change, Japanese people have more chance to learn about co-ethnics living and working outside their home country. Some former success stories of such people offer them a concrete role model of Japanese diaspora entrepreneurs. Role models are regarded as one of the significant factors of entrepreneurial motivation in the previous literature (Bosma et al., 2012). In fact, 6 out of 8 entrepreneurs $(1,2,3,6,7,8)$ confirmed that they had a certain role model of Japanese diaspora entrepreneurs. For instance, entrepreneur 3, who founded an online Spanish school in Guatemala, was inspired by the online English school market in the Philippines which was established by Korean and Japanese diaspora entrepreneurs a decade ago.

The second environmental change plays a role in altering people's perception as well as networks. The frequent contact with people from different cultural backgrounds in their childhood as well as in their working place fosters people's overall curiosity about foreign cultures. Entrepreneur A, for instance, decided to move to England when he was 19 due to the aspiration to get to know foreign cultures. Entrepreneur 3 also made a choice to quit his well-paid job to make a world trip with his friends in his mid-20s. Such curiosity is an important element of one's global mindset, which is 
the concept defined as one that combines an openness to and awareness of diversity across cultures and markets with a propensity and ability to synthesize across this diversity (Gupta \& Govindarajan, 2002). According to Gupta and Govindarajan (2002), curiosity about the world is shaped strongly by early childhood experience as well as working environments when one is a younger workforce member. Besides, an increasing number of people have friends, acquaintances, or colleague who have other cultural backgrounds in their personal network. It makes a contribution for some Japanese to have an emotional connection to a certain country. For instance, entrepreneur 1 decided to found his company to improve working conditions for a Filipino English teacher he got to know via the internet. Entrepreneur 4 got to know his Chilean wife in Japan, who played a decisive role in his decision to become an entrepreneur in Chile. In a similar vein, entrepreneur 7 chose Philippines as his $\mathrm{COO}$ because of his Filipino wife.

The second factor is technological development especially in the communications and transportation sector. Such technological advancement changes mainly two aspects of Japanese diaspora entrepreneurs. The first aspect is in line with the points argued by Yeung (2002) on general diaspora entrepreneurs that technological development of information and communication technology reduces the barriers to changing locations in the modern society. Unlike the earlier time, modern migrants are able to maintain their connection to their $\mathrm{COO}$ more easily through a great variety of communication channels including digital social media such as Facebook and Skype as well as low cost transportation methods.

Another impact of technological development could be observed in their business model. New and innovative information and communication technology enables entrepreneurs to create an innovative business model. While classic business fields of migrants are trading and ethnic business (cf. Cohen 2008), especially younger entrepreneurs observed in the cases integrate such a digital component strongly into their business model. Entrepreneur 1's business model is a representative example. Although entrepreneur 1's firm has its corporate address in Japan, it does not have a physical facility. He has more than 20 employees all of whom are located in the Philippines and Argentina. He himself is currently living in Mexico and outsources many managerial tasks including legal and accounting issues to professionals in India, Argentina, Bolivia, and the Dominican Republic. His business model relies heavily on digital elements. Besides entrepreneur 1, entrepreneurs 3 and 7 also offer their services through the internet.

The third significant factor on the macro level is economic situations both in Japan and in emerging countries. Japan has suffered from an economic stagnations since 1991, when Japan experienced the Japanese asset price bubble (Dehesh \& Pugh, 1999). People in Japan lost economic perspectives due to this stagnation. For instance, entrepreneur 3 carefully describes his career situation as follows: "I had seen my Senpai ${ }^{1}$ (at the company). If I work 2 or 3 more years, I will be maybe in that kind of position (...). That didn't really motivate me." Additionally, most of the Japanese people face the so-called "middleclass dilemma" as pointed out by Horiuchi (2010). "Middle-class dilemma" describes the frustration that more than $95 \%$ of the Japanese people feel they belong to the middle class regardless their career efforts. Some people start seeking for alternative opportunities outside Japan due to the severe working conditions which do not even offer an appropriate outcome (e.g. getting out of the middle class). On the one hand, Japanese entrepreneurs felt a sort of frustration in the Japanese economic situation as well as their own working conditions. On the other hand, they saw rapidly growing emerging economies. Entrepreneur 1 indicates it as follows "(...) in terms of opportunities, sure, there are a lot more opportunities here (= Latin America) than for instance in Japan."

To sum up, changing factors on the macro level also influence the meso-level factors, which eventually changed their perception on the micro level. What is worth mentioning here is that all of 8 observed entrepreneurs confirmed that they would not have become entrepreneurs in Japan, even though they were interested in starting their own business.

However, having an interest in becoming an entrepreneur was not sufficient to have them make a decision to become 


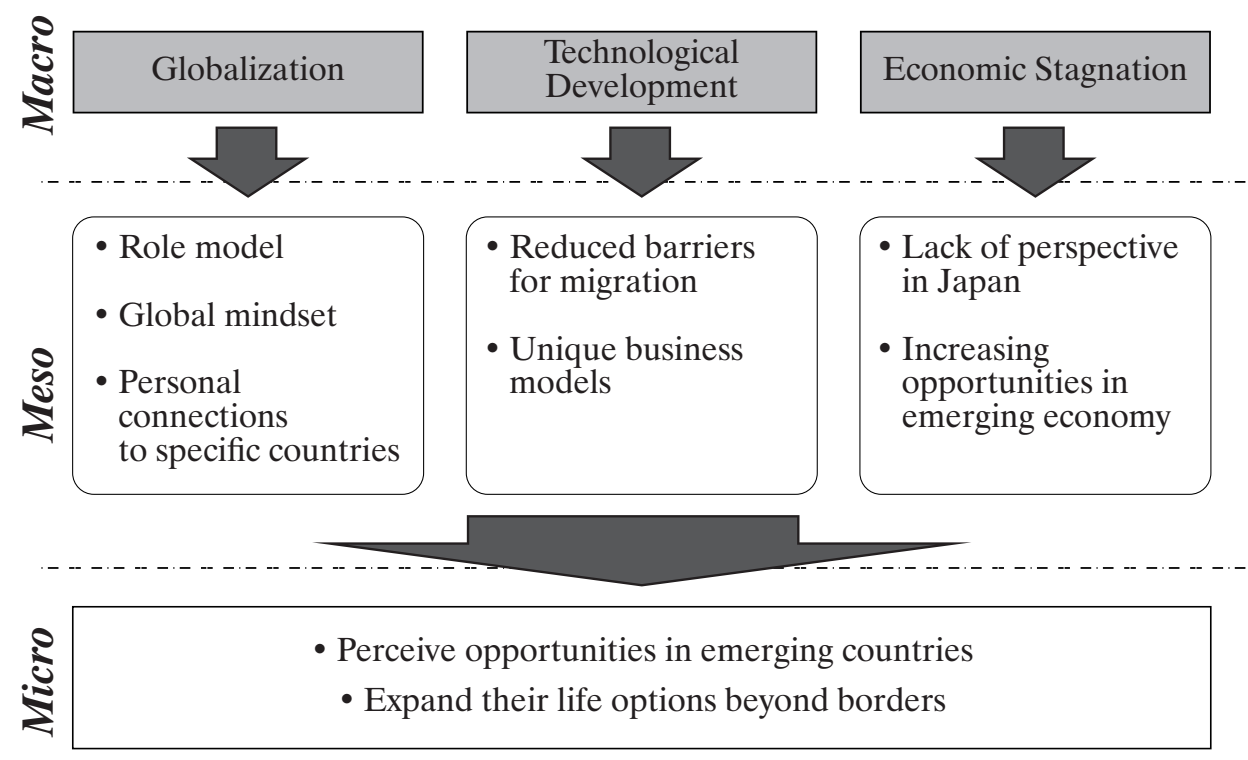

entrepreneurs in Japan. Interviewed entrepreneurs named mainly three points lacking in Japan: (i) lack of opportunities, (ii) lack of contribution, and (iii) lack of challenge. First, entrepreneurs thought that Japanese markets are saturated and it is difficult to find promising opportunities. Second, observed Japanese diaspora entrepreneurs do not perceive offering novel and additional values to Japanese customers as a significant social contribution, as Japanese people already enjoy a high living standard. Entrepreneur 3 explained why he did not make a decision to start his own business in Japan: "I did not have WHY in Japan. WHY do I really wanna do this business? WHY do I need to do this business?" The case studies show that some find more meanings in offering more values to the people in emerging economies. Third, some entrepreneurs have a strong need for achievement and did not perceive it as a recognizable achievement to become entrepreneurs in Japan. They found it more challenging to start their own business in emerging countries due to institutional differences.

The cases show that various factors on the macro level influence the meso-level factors, which eventually change an individual's perceptions on the micro level. Owing to these changes, they perceive unique chances in emerging countries as realistic life options. Observing the cases, a mechanism becomes visible how Japanese individuals turn the three lacks discussed above in Japan into unique opportunities through adding a transnational dimension. The mechanism discussed in this section is illustrated in Figure 1.

\section{Six Main Motivational Factors}

Through data coding (Saldaña, 2008) of eight empirical cases, six main motivational factors are identified: (i) contribution to COR, (ii) contribution to COO, (iii) seeking for challenge, (iv) aspiration for freedom, (v) opportunity exploitation, and (vi) intercultural curiosity. In this section, these six factors are briefly defined and possible measures are discussed.

\subsection{Contribution to COR}

First, "contribution to COR" refers to the degree of willingness of entrepreneurs to have positive social impacts on the society of CORs. It was named as one of the main motivations by entrepreneurs 1 and 3 . In their cases, the primal motivation was to improve teachers' working conditions in COR. Entrepreneurs 2 and 5 show also a moderately high degree of "contribution to COR" by focusing on ensuring fair treatment to their local employees in CORs. Entrepreneur 2 offers free accommodation, food, the internet access and water for all of his employees and additionally the start salary is twice as high as the average salary in Manila. He also offers various skill training programs for his employees. Entrepreneur 5 has had a strong 
policy to treat all of his local employees as family by taking care of them also privately.

They seem to be driven by altruistic motivation, which has a different nature from altruism advocated by Gillespie et al. (1999). Unlike the diaspora altruism, Japanese entrepreneurs do not have any ethnical connection to COOs. Their altruistic motivation to contribute to COR may be explained by findings in the former research on social entrepreneurship. Social entrepreneurs are different from profitoriented entrepreneurs in terms of their "desire to bring about social change" (Mair \& Marti, 2006). Social entrepreneurs are driven by social mission in addition to other motivational factors (Austin et al., 2006), as these Japanese entrepreneurs are driven by the strong desire to improve working conditions in CORs.

\subsection{Contribution to $\mathrm{COO}$}

Second, "contribution to COO" refers to the degree of willingness of entrepreneurs to contribute to a positive country reputation of $\mathrm{COO}$ and to improve the society of $\mathrm{COO}$ through their services/products. This type of motivation can partly be explained by social and emotional aspects of diaspora motivation named by Nilsen and Riddle (2007). One thing that can be commonly noticed among observed entrepreneurs, except entrepreneur 6, is a strong willingness to represent Japan in a foreign country. They stick to "the success as the Japanese" through their business. Similar to the suggestion by Nkongolo-Bakenda and Chrysotome (2013), recognition from the Japanese society seems to be very important to them, considering the fact that half of them (entrepreneurs 1, 2, 3, and 8 ) continuously update the current corporate situation on Facebook or Twitter in Japanese instead of in English or the local language. Since Japan has less visible social and political problems than emerging and developing countries, altruistic motivation (Gillespie et al., 1999) seems to be less relevant to Japanese entrepreneurs, although all of them target Japanese customers. The willingness to change political or economic conditions in COO does not seem to be their central motivation.

Interestingly enough, the observed aspiration for the social contribution to $\mathrm{COO}$ was not as significant as the one to COR.
While the willingness to change the Japanese society was observable in entrepreneurs 2 and 3, other entrepreneurs use well-endorsed Japanese resources such as country image, technology, or lucrative customer groups for rather commercial purposes, even though they make indirect contributions to $\mathrm{COO}$ through offering unique service from outside of the country. Overall, observed entrepreneurs do not appear to feel the necessity or significance of contributions to Japan.

\subsection{Seeking for Challenge}

Third, "seeking for challenge" describes one's attitude to seek for visible and meaningful challenges. This concept is similar to the need for achievement (Hansemark, 2001; McClelland, 1990) in the literature on entrepreneurial motivation. From such behaviors of entrepreneurs, their strong willingness to change existing conditions within the COR society can be deduced. As discussed in the previous section, Japanese entrepreneurs in the case studies did not want to become entrepreneurs in Japan partly because of a lack of contribution, even though they were interested in running their own business. This can be interpreted that their need for achievement would have not been fulfilled in Japan. In emerging countries like their COR, social problems entrepreneurs perceived were more significant, which motivated them to accomplish their mission to solve them. Also it is noticeable that some of entrepreneurs perceive it more challenging to become an entrepreneur in unknown country contexts than in Japan.

\subsection{Aspiration for Freedom}

Fourth, "aspiration for freedom" refers to one's desire to be free from societal pressure in COO. This concept has a certain similarity to "the need for escape" identified by Scheinberg and MacMillan (1988). In the case of Japanese entrepreneurs, the reason why they want to escape can be explained by the middle-class dilemma suggested by Horiuchi (2010). Some of the observed entrepreneurs felt a certain frustration in Japan. Entrepreneurs 3, 4 and 6 were not fully satisfied with their vocational situation in Japan, even though they had a well-paid job. Entrepreneur 4 named a lacking work-life balance in Japan as a crucial determinant for his entrepre- 
neurial motivation. One of the determinants for entrepreneur 7 to choose the Philippines as COR was his strong willingness not to succeed to his father's business. If he had stayed in Japan, he would have had to succeed to his father's business. This "aspiration for freedom" is the only push factor (cf. Amit \& muler, 1995) among six main motivational factors of Japanese descending diaspora entrepreneurs and has not been discussed by previous scholars of diaspora entrepreneurship.

\subsection{Opportunity Exploration}

Fifth, "opportunity exploitation" describes one's willingness to exploit perceived opportunities in transnational settings. This factor was more visible than other motivational components in many cases. Mainly three types of opportunities are observed. The first transnational opportunity is classic trading (export \& import) between Japan and COR. Trading is not a specific opportunity to Japanese diaspora entrepreneurs. It is rather one of the traditional and typical sectors in diaspora entrepreneurship (Cohen, 2008; Rauch \& Trindade, 2002; Wong, 2004). Entrepreneurs 5 and 7 started their business in the trading sector. The second opportunity is economic gaps between Japan and emerging countries. Using a lowcost labor force, they offer their service digitally to the Japanese customers in Japan. The third group is selling Japanese services or products to the Japanese expatriates or local populations in COR. Observed entrepreneurs identified unique business opportunities in such transnational contexts. Such opportunity identifications played a crucial role in their decision-making process to become entrepreneurs in CORs. While it is more than common for entrepreneurs to be driven by opportunities (cf. Smallbone \& Welter, 2004) and for ascending diaspora entrepreneurs to be also often motivated by opportunities such as income increase (Kalltany \& Visser, 2010) or financial rewards (Nielsen $\&$ Riddle, 2007), the case studies show that descending diaspora entrepreneurs possess an ethnic advantage (Gillespie et al., 1999) because of their COO. In the cases, all of entrepreneurs target Japanese customers either physically or digitally. Such Japanese entrepreneurs have a natural legitimacy to address the needs of Japanese customers as explained by Bonacich and Modell (1980). But one difference between descending and ascending diaspora entrepreneurs is that their ethnic customers are lucrative and premium, unlike the customers in emerging or developing countries, which enhances the attractiveness of the opportunity.

\subsection{Intercultural Curiosity}

Sixth, "intercultural curiosity" is an overall interest of people in living and working in an unknown cultural context. What was common in the observed Japanese entrepreneurs was their overall curiosity in foreign contexts and especially emerging countries. Entrepreneur 3 implies as follows: "if there are two job options with same work content and same quality, then I would always choose the one in foreign countries." Entrepreneur 3 lived in the US when he was a child, which is in line with the arguments by Gupta and Govindarajan (2002) that intercultural experience in childhood influences global mindsets. Entrepreneur 5 explained his country choice (Argentina) by saying he wanted "to start a business in a totally new environment." The cases support the statement that entrepreneurs who have global mindsets are curious about foreign cultures and, therefore, they perceive the choice to become an entrepreneur in unknown country contexts as more attractive.

\section{Conclusion}

This paper explores entrepreneurial motivation of descending diaspora entrepreneurs. 8 case studies with Japanese people who decided to migrate to emerging countries to become entrepreneurs were conducted with a grounded theory approach (Charmaz, 2003; 2014).

Based on the case studies and iterative analysis process, this study discovered multidimensional interrelated factors which influence the motivation dynamics of Japanese entrepreneurs in emerging economies. Globalization, technological development and economic stagnation are identified as the macro-level factors which influence meso and eventually micro levels. To understand such environmental impacts on the Japanese society and individuals, six main motivational elements are categorized: (i) contribution to COR, (ii) contribution to $\mathrm{COO}$, (iii) seeking for challenge, (iv) aspiration for freedom, (v) opportunity exploitation, and (vi) intercultural curiosity. While some of 
these elements are similar or comparable to previous findings from the literature on diaspora entrepreneurship and entrepreneurship, "contribution to COR", "aspiration for freedom" and "intercultural curiosity" are novel forms of motivation which is unique to this population, also compared to ascending diaspora entrepreneurs. This study suggests that descending diaspora entrepreneurs are driven by the mixture of these six different motivations.

This study has a few limitations. First, this study is based on one specific ethnic group. As entrepreneurial motivation is deeply embedded in a country's institutional context, it is unknown to which extent these findings are applicable to other countries. Second, the interpretation process was conducted by a single author. Therefore, this study cannot get a rid of bias especially in scoring six motivational indicators. Involving additional researchers in the interpretation process will enable a collaborate analysis (Strauss, 1987: 138-139).

Despite these above mentioned weaknesses, this paper offers novel insights. This paper tackles a common challenge in the research on entrepreneurial motivation by considering multi-level institutional factors which influence one's motivation formulation. It also sheds light on an overlooked transnational dimension in entrepreneurial motivation. For the research on diaspora entrepreneurship, the results of this paper emphasize the importance to consider the complexity of mixed motivation on a number of levels in the future research.

As a next step, more studies on Japanese descending diaspora entrepreneurs can be conducted to enhance the robustness of the findings and develop measurements of each of six motivational dimensions. It enables us to visualize and grasp an entire picture of their motivation mix. It will be helpful to apply the findings to other diaspora groups.

\section{Footnotes}

1 Senpai is a Japanese term which refers to the people who started working earlier than himself.

\section{References}

Aldrich, H. E. \& Waldinger, R. (1990). Ethnicity and entrepreneurship. Annual Review of Sociology, $16,111-135$.
Amit, R. \& Muller, E. (1995). "Push" and "Pull" entrepreneurship. Journal of Small Business \& Entrepreneurship, 12(4), 64-80.

Arenius, P. \& Minniti, M. (2005). Perceptual variables and nascent entrepreneurship. Small business economics, 24(3), 233-247.

Atkinson, J. W. (1957). Motivational determinants of risk-taking behavior, Psychological Review 64(6-1), 359-372.

Austin, J., Stevenson, H. \& Wie-Skillern, J. (2006). Social and commercial entrepreneurship: same, different, or both? Entrepreneurship theory and practice, 30(1), 1-22.

Babb, E. M. \& Babb, S. V. (1992). Psychological traits of rural entrepreneurs. Journal of Socio-Economics, 21(4), 353-362.

Bamberger, I. (1986). The Stratos Project: Theoretical bases and some first descriptive results, Paper presented at the 4th Nordic Research Conference on Small Business, Umeå/Vasa, June 4-6.

Baumol, W. J. (1990). Entrepreneurship, productive, unproductive and destructive. Journal of Political Economy, 98(5), 893-921.

Bird B. J. (1989). Entrepreneurial behavior. Glenview IL: Scott.

Bonacich, E. \& John M. (1980). The ethnic basis of economic solidarity. Berkeley: University of California Press.

Bosma, N., Hessels, J., Schutjens, V., van Praag, M. \& Verheul, I. (2012). Entrepreneurship and role models. Journal of Economic Psychology, 33(2), 410-424.

Brinkerhoff, J. M. (2004). Digital diasporas and international development: Afghan-Americans and the reconstruction of Afghanistan. Public Administration and Development, 24(5), 397-413.

Brinkerhoff, J. M. (2006). Digital diasporas and conflict prevention. The case of Somalinet.com. In Review of International Studies, 32(1), 25-47.

Brinkerhoff, J. M. (2011). Diasporas and conflict societies: conflict entrepreneurs, competing interests or contributors to stability and development? Conflict, Security \& Development, 11(2), 115-143.

Brinkerhoff, J. M. (2012). Creating an enabling environment for diasporas' participation in homeland development. International Migration, 50(1), 75-95.

Carsrud, A. \& Brännback, M. (2011). Entrepreneurial motivations. What do we still need to know? Journal of Small Business Management, 49(1), 9-26.

Charmaz, K. (2014). Constructing grounded theory. 2nd. Edition: Sage Publications.

Choo, S. \& Wong, M. (2006). Entrepreneurial intention. Triggers and barriers to new venture creation. Singapore. Singapore Management Review, 28(2), 47-64. 
Cohen, R. (1996). Diasporas and the nation-state. From Victims to Challengers. International Affairs (Royal Institute of International Affairs 1944-), 72(3), 507-520.

Cohen, R. (2008). Global diasporas: An introduction (2nd ed.). London: Routledge.

Collins, C. J., Hanges, P. J. \& Locke, E. A. (2004). The relationship of achievement motivation to entrepreneurial behavior: A meta-analysis. Human performance, 17(1), 95-117.

Constant, A., Shachmurove, Y. \& Zimmermann, K. F. (2003). What makes an entrepreneur and does it pay?: Native men, Turks, and other migrants in Germany, IZA Discussion paper series, 940.

Constant, A. \& Shachmurove, Y. (2003). Entrepreneurial ventures and wage differentials between Germans and immigrants. Discussion Paper series, Forschungsinstitut zur Zukunft der Arbeit, 879.

Davidsson, P. (1989). Continued entrepreneurship and small firm growth. Stockholm: The Economic Research Institute. A Dissertation for the Doctor's Degree in Business Administration, Stockholm School of Economics.

Davidsson, P. (1991). Continued entrepreneurship: ability, need and opportunity as determinants of small firm growth. Journal of Business Venturing, 6(6), 405-429.

Dehesh, A. \& Pugh, C. (1999). The internationalization of post - 1980 property cycles and the Japanese 'bubble'economy, 1986-96. International Journal of Urban and Regional Research, 23(1), 147-164.

Denzin, N. (1970). The research act in sociology. Chicago: Aldine.

Dutia, S. G. (2011). Diaspora networks. A new impetus to drive entrepreneurship. Innovations, 7, Winter 2012, 65-72.

Eisenhardt, K. M. (1989). Building theories from case study research. The Academy of management Review, 14(4), 532-550.

Elo, M. (2013). Diaspora entrepreneurs in and from an emerging market. Narratives from Uzbekistan. 12th Vaasa Conference on International Business. Vaasa, Finland, 21-23.08.

Elo, M. (2014). Diaspora networks in international business and transnational entrepreneurship - A literature review. ZenTra Working Paper.

Fatoki, O. \& Patswawairi, T. (2012). The motivations and obstacles to immigrant entrepreneurship in South Africa. Journal of Social Sciences, 32(2),133-142.

Gupta, A. K. \& Govindarajan, V. (2002). Cultivating a Global Mindset. The Academy of Management Executive, 16(1), 116-126.
Hamilton, R.T. (1988). Motivations and Aspirations of Business Founders, International Small Business Journal, 6(1), 70-78.

Hansemark, O. C. (2003). Need for achievement, locus of control and the prediction of business startups: A longitudinal study. Journal of economic Psychology, 24(3), 301-319.

Harima, A. (2014). Network dynamics of descending diaspora entrepreneurship: Multiple case studies with Japanese entrepreneurs in emerging economies. Journal of Entrepreneurship, Management and Innovation, 10(4), 65-92.

Huang, Y. \& Khanna, T. (2003). Can India overtake China? Foreign Policy.

International Organization for Migration (2014). Health in the Post-2015 Development Agenda. The Importance of Migrants' Health for Sustainable and Equitable Development. Available online at https:/www.iom.int/files/live/sites/iom/files/WhatWe-Do/docs/Health-in-the-Post-2015-Development-Agenda.pdf, checked on 30 March, 2014.

Johnson, B. R. (1990). Toward a multidimensional model of entrepreneurship: The case of achievement motivation and the entrepreneur. Entrepreneurship Theory and Practice, 14(3), 39-54.

Kapur, D. (2001). Diasporas and Technology Transfer. Journal of Human Development, 2(2), 265-286.

Kent, G. (Ed.) (2005). Diaspora power. Network contributions to peacebuilding and the transformation of war economies. Transforming War Economies Seminar. Plymouth, 16-18 June 2005.

Ketkar, S. L. \& Ratha, D. (2010). Diaspora bonds: Tapping the diaspora during difficult times. Journal of International Commerce, Economics and Policy, 1(2), 251-263.

Kloosterman, R., van der Leun, J. \& Rath, J. (1999). Mixed embeddedness. (In)formal economic activities and immigrant business in the Netherlands. International Journal of Urban and Regional Research, 23(2), 253-267.

Kuratko, D. F., Hornsby, J. S. \& Naffziger, D. W. (1997). An examination of owners' goals in sustaining entrepreneurship, Journal of Small Business Management, 35(1), 24-33.

Kuznetsov, Y. (2006). Diaspora networks and the international migration of skills. How Countries Can Draw on Their Talent Abroad. Washington DC: World Bank Publications (WBI Development Studies).

Light, I., Bhachu, P. \& Karageorgis, S. (1993). Migration networks and immigrant entrepreneurship. In: I. Light \& P. Bhachu, Immigration and entrepreneurship: Culture, capital, and ethnic networks, 25-50.

Lofstrom, M. (1999). Labor market assimilation and the self-employment decision of immigrant entrepreneurs, IZA Discussion paper series, 54. 
London, M. (2010). Understanding social advocacy. An integrative model of motivation, strategy, and persistence in support of corporate social responsibility and social entrepreneurship. Journal of Management Development, 29(3), 224-245.

Mair, J. \& Marti, I. (2006). Social entrepreneurship research: A source of explanation, prediction, and delight. Journal of world business, 41(1), 36-44.

Masurel, E., Nijkamp, P., Tastan, M. \& Vindigni, G. (2002). Motivations and performance conditions for ethnic entrepreneurship. Growth and Change, 33(2), 238-260.

McClelland, D. C. (1961). The Achieving Society. Princeton, NJ: Van Nostrand, 1961. Print.

McClelland, D. C. (1990). Human motivation. Cambridge: Cambridge University Press.

Meyer, J.-B. (2007). Building sustainability. The new frontier of diaspora knowledge networks. The conference on 'Transnationalisation and Development(s): Toward a North-South Perspective'. Center for Interdisciplinary Research Bielefeld (Germany), 31 May - 1 June, 2007. 35 volumes: COMCAD Arbeitspapiere - Working Papers.

Minto-Coy, I. D. (2010). The Impact of the Global Financial Crisis on Remittancing: Implications for Developing Countries.

Mohamoud, A. \& Osman, S. (2008). The African Diaspora as agents of peace on the continent. Conflict Trends (4), 38-44.

Newland, K. \& Tanaka, H. (2010). Mobilizing diaspora entrepreneurship for development. Washington DC: Migration Policy Institute.

Nielsen, T. M. \& Riddle, L. (2009). Investing in peace: The Motivational Dynamics of Diaspora Investment in Post-Conflict Economies. Journal of Business Ethnics, 89(S4), 435-448.

OECD (2013). International migration outlook 2013. OECD Publishing. Available online at http://dx.doi. org/10.1787/migr_outlook-2013-en, checked on 31st of October, 2014.

Ojo, S. (2012). Ethnic enclaves to diaspora entrepreneurs: A critical appraisal of black British Africans' Transnational Entrepreneurship in London. Journal of African Business, 13(2), 145-156.

Ojo, S., Nwankwo, S. \& Gbadamosi, A. (2013). Ethnic entrepreneurship: the myths of informal and illegal enterprises in the UK. Entrepreneurship \& Regional Development: An International Journal, 25(7-8), 587-611.

Okafor, C. \& Amalu, R. (2010). Entrepreneurial motivation as determinants of women entrepreneurship challenges. Petoroleum-Gas University of Ploisti BULLETIN 2, 66-77.

Orozco, M. (2009). Emerging markets for Rwanda: remittance transfers, its marketplace and financial intermediation. Report, Inter-American Dialogue, Washington, DC.

Poirine, B. (2006). Remittances sent by a growing altruistic diaspora: How do they grow over time? Asia Pacific Viewpoint, 47(1), 93-108.

Rath, J. (2000). Introduction; Immigrant Business and the Economic, Politico-Institutional and Social Environment. In: J. Rath (ed.), Immigrant Business: The Economic, Political and Social Environment. London: Macmillan Press, 1-12.

Rauch, J. E. \& Trindade, V. (2002). Ethnic Chinese networks in international trade. Review of Economics and Statistics, 84(1), 116-130.

Renko, M., Kroeck, K. G. \& Bullough, A. (2012). Expectancy theory and nascent entrepreneurship. Small Business Economics, 39(3), 667-687.

Riddle, L. (2008). Diaspora: exploring their development potential. ESR Review, 10(2), 28-36.

Riddle, L. \& Brinkerhoff, J. (2011). Diaspora entrepreneurs as institutional change agents: The case of Thamel.com. International Business Review, 20, 670-680.

Robichaud, Y., McGraw, E. \& Roger, A. (2001). Toward the development of a measuring instrument for entrepreneurial motivation. Journal of Developmental Entrepreneurship, 6(1), 189-202.

Rubyutsa, J. M. (2012). The Role of Remittance in Development: The case of Rwandan Diaspora' Remittances. Rwanda Journal, 26(1), 120-132.

Safran, W. (1991). Diasporas in modern societies. Myths of homeland and return. A Journal of Transnational Studies, 1(1), 83-99.

Saldaña, J. (2012). The coding manual for qualitative researchers (No. 14). Sage.

Sanders, J. M. \& Nee, V. (1996). Immigrant selfemployment: The family as social capital and the value of human capital. American Sociological Review, 61(2), 231-249.

Saxenian, A. (2002). Transnational communities and the evolution of global production networks. The cases of Taiwan, China, and India. Working Paper. EAST-WEST CENTER.

Saxenian, A. (2005). From brain drain to brain circulation. Transnational communities and regional upgrading in India and China. Studies in Comparative International Development, 40(2), 33-61.

Scheinberg, S. \& MacMillan I.C. (1988). An 11 country study of motivations to start a business, frontiers of entrepreneurship research 1988. Wellesley, MA.: Babson College.

Schumpeter, J. A. (1934). The theory of economic development. Oxford: Oxford University Press.

Shaver, K. G. \& Scott, L. R. (1991). Person, process, choice: The psychology of new venture creation. Entrepreneurship theory and practice, 16(2), 23-45. 
Singh, K. P. (1993). Women entrepreneurs. The profile and motivation. The Journal of Entrepreneurship, 2(1), 47-58.

Smallbone, D. \& Welter, F. (2004). Entrepreneurship in transition economies: necessity or opportunity driven? Presented at the Babson-Kaufmann entrepreneurship Research Conference (BKERC), https:// www.researchgate.net/publication/235966724_Entrepreneurship_in_transition_economies_Necessity_or_opportunity_driven (retrieved 5 September, 2015).

Smallbone, D. \& Welter, F. (2001), The Distinctiveness of entrepreneurship in transition economies. Small Business Economics, 16(4), 249-262.

Strauss, A. (1987). Qualitative analysis. N. Y.: Cambridge University Press.

Tchouassai, G. \& Sikod, F. (2010). Altruistic preferences as motivation for migrants in the diaspora to remit to home communities. Research in Applied Economics, 2(1), 1-18.

Thomsen, T. L. (2006). Immigrant entrepreneurship as gendered social positions. A study on motivations and strategies in a biographical perspective. $\mathrm{PhD}$ Thesis. SPIRIT Doctoral Programme, Aalborg.

Van Eerde, W. \& Thierry, H. (1996). Vroom's expectancy models and work-related criteria: A meta-analysis. Journal of Applied Psychology, 81(5), 575-586.

Van Gelderen, M., Brand, M., Van Praag, M., Bodewes, W. \& Van Gils, A. (2008). Explaining entrepreneurial intentions by means of the theory of planned behaviour. Career Development International, 13(6), 538-559.

Van Praag, C. M. \& Cramer, J. S. (2001). The roots of entrepreneurship and labour demand: Individual ability and low risk aversion. Economica, 68(269), 45-62.

Vemuri, S. R. (2014). Formation of diaspora entrepreneurs. ZenTra Working Papers in Transnational Studies, 41/2014 (November).

Volery T, Doss, N, Mazzarol, T. \& Thein, V. (1997). Triggers and barriers affecting entrepreneurial intentionality: the case of western Australian nascent entrepreneurs. Journal of Enterprising Culture, 5(3), 273-291.

Wong, L. L. (2004). Taiwanese immigrant entrepreneurs in Canada and transnational social space. International migration, 42(2), 113-152.

World Bank (2011). Migration and Remittances. Factobook 2011. Available online at http://issuu.com/ world.bank.publications/docs/9780821382189? $\mathrm{e}=0$, checked on 30 March, 2014.

Yalcin, S. \& Kapu, H. (2008). Entrepreneurial dimensions in transitional economies: A review of relevant literature and the case of Kyrgyzstan. Journal of Developmental Entrepreneurship, 13(2), 185-203.

Yeung, H. W.-C. (2002). Entrepreneurship in international business. An institutional perspective. Asia Pacific Journal of Management, 19, 29-61. 